\title{
Globalization and the Collective Action of the Socially Excluded in France: At the Heart of the Margins?
}

This article examines the mobilizations of the socially excluded in France as they relate to issues of globalization. We consider the manner in which these "have-not" movements (the unemployed, the homeless, undocumented persons) became and continue to be mobilized around alter-globalization $^{1}$ issues in relation with a number of other social actors.

In our view, the have-not mobilizations are not solely dependent upon the internal dynamics of the movement, nor upon the relationships with various national and international institutions; rather, these mobilizations rely also on the relations they have with other collective actors involved in globalization issues, such as unions and organizations such as the Association pour la taxation des transactions pour l'aide aux citoyens (ATTAC - Association for the Taxation of Financial Transactions to Aid Citizens). To ascertain this aspect of mobilizations fully, we propose a discussion of what we called the French "global space of protest". Using an approach inspired by the work of Lévy (1994), we define this global space of protest along three dimensions: the content, the scope and the privilege mode of belonging (first part).

We demonstrate how the building of the global space of protest in France was punctuated by two moments. ${ }^{2}$ The first corresponds to the gradual convergence of social actors around the issue of globalization. This convergence was centered on a renewal of activists' discourses, the development of multiple scales of mobilizations and a functional division of tasks among the actors. The second moment corresponds more to the crystallization of divisions among the actors. These divisions are articulated around different conceptions of what the struggle's aims should be and stemmed from differences regarding the sense of belonging to the global space of protest. In the timeframe we are considering (mid-1990s to 2005), the history of convergence placed the have-nots at the heart of alter-globalist mobilizations (second part), whereas the history of divergence translated into a "decentering" of the place of the have-nots within this space (third part). Their progressive marginalization also reveals the transformations of struggles against globalization in France. 


\section{Understanding the Have-Not Mobilizations against Globalization}

In France, have-not mobilizations played a crucial role and constituted a driving force in alterglobalization mobilizations (Mouchard, 2005). However, the literature on collective action against economic globalization makes scant reference to the role of the socially excluded. In contrast, most studies have widely documented the fact that these mobilizations were spurred, rather, by an elite group of educated activists who belonged mostly to the middle class of Northern democratic societies, as opposed to its more disadvantaged fringe groups (della Porta et al., 2006; Agrikoliansky and Sommier, 2005). According to the dominant stream of literature, alter-globalist activists on the whole possess significant material and cognitive resources, they have the means to travel around the world (or at least in Europe); they are able to communicate in various languages; and they are strongly connected to a host of local and transnational networks (Tarrow, 2007). In other words, they do not fit the profiles of the unemployed and of undocumented persons.

As we attempt to appreciate the reasons underlying these "unlikely mobilizations" (Mathieu, 2007: 187), two major avenues are available to us: (1) to understand the involvement of the have-nots in alter-globalization issues based on the transnational practices developed by activists, and (2) to analyze the unique relationships that developed between the have-not movements and other social movements involved in alter-campaigns in France.

The first line of studies examines the transnationalization of have-not mobilizations in Europe in the mid-1990s. These studies have employed the classic boomerang effect and spiral model (Sikking, 2005: 171) to explain the collective action of the unemployed in France vis-à-vis European institutions and the organization of activists from various European countries into networks. The boomerang effect and spiral model describe a series of actions that occur when activists, who are operating within a domestic opportunity structure that is closed due to repression or exclusion from the national system of representation, search for international allies from more open international political opportunity structures in order to apply pressure on their national government "from above." The mobilizations of the unemployed at the end of the 1990s and the emergence of the European marches against unemployment follow this logic, at least in part (Chabanet, 2002). According to Christophe Aguitton, who was involved in the network 
Action contre le chômage! (AC! - Action against Unemployment!), European mobilizations of the unemployed enabled the transformation of initial protests focusing on social minimum increases into rights claims (the right to employment, the right to a minimum income) and their presentation as such in the national space (Aguitton, 2002). Though fragile, movements of the unemployed enjoyed a certain measure of success at the national level due in part to their new European visibility. For example, in 1998, organizations of the unemployed were formally received by the State and were invited to the tripartite bargaining table for the first time in their life, against the advice of certain unions. Following these negotiations, material gains were made with the adoption of the Social Emergency Fund, the enactment of a law against social exclusion and the raising of social minimums (Belorgey, 2000). Lastly, the Europeanization of their actions also gave them a second wind, with the main associations defending the unemployed and AC! having been destabilized by the decrease in unemployment at the end of the 1990s and disoriented by their success. ${ }^{3}$ Chabanet (2002) has demonstrated how the mobilizations against unemployment that targeted the European Union were archetypical of the externalization process described by Imig and Tarrow (2001); the European Union offered an additional level of opportunity, a sounding box, compelling national States to respond to demands made at the European level.

In studies of this nature, little attention is paid to the specific character of the have-not mobilizations; at best, they are treated like other types of mobilizations. It is our view, as well as that of others, that the mobilizations of the socially excluded are unlike other types of mobilizations (Royall, 2009; Mouchard, 2007). They can be distinguished by the origins of the activists (position at the margins of the social and political space, poor resources, a distant and even hostile relationship with institutions) as well as by the very nature of the collective action they initiate. Some studies have addressed the presence of left and extreme-left professional activists at the head of these movements and the use of certain courses of action (legal recourse as well as direct actions that were sometimes illegal and often spectacular) (Péchu, 1996: 115; Della Porta, 2005; Mouchard, 2002).

A second, more recent, stream of studies addresses the role of have-not mobilizations within alter-globalist mobilizations and considers the specific characteristics of these have-not mobilizations. This literature discusses the fragility of the mobilizations against globalization and the "problematic" nature of their place in the field of collective action (Giraud et al., 2005). In 
this context, the relation of have-not collective action with respect to other protest actors is central to the analysis. Have-not mobilizations and their transformations no longer solely depend upon factors that are internal to the movement, nor do they solely depend upon the relationship of these actors with national and international institutions. They are also affected by their relationships with other collective actors involved in the same issues. Several studies have underscored the importance of understanding alliances with unions, charitable associations and/or "left-wing political" organizations in general in order to understand the very existence of these mobilizations (Della Porta, 2005; Fillieule 1993; Chabanet and Faniel, 2009). However, beyond the issue of their emergence, it is also important to consider the issue of "borders" of the movement. This issue is relevant for actors that are on the outside the alter-globalist movement, asking themselves if they (should we be in or not; but also for other actors inside the alterglobalist movement asking themselves if the "others" should be there or not, and if so, how?. The study of Choukri Hmed (2007) on groups and networks representing people living in workingclass neighborhoods in France demonstrates how this constant dialectic participates to the transformations that occurred in both groups.

In line with these studies, and with a view to grasping this aspect of the relational dynamics of mobilizations, we propose to consider the French "global space of protest" (Dufour, 2006) so as to shed light on the context and significance of the dynamics between the actors. Further to the work of Lilian Mathieu $(2007 ; 2004)$, it is our view that politics can be divided into different spaces, with borders that are not fixed in time but that provide a structure nonetheless. The global space of protest is defined by the creation of a form of conflict surrounding a theme which has also been created (globalization in this case). From this perspective, the social and political dynamics (such as the remodeling of the Left) are not contextual elements; rather, they are elements belonging directly to the "building" of the global space of protest. The autonomy of a space of protest depends upon its capacity to exist for the purposes of a specific struggle and not as an instrument for other struggles.

Our conceptualization of the space of protest is anchored in the work of Lévy, who describes three aspects of space: the scale, the metric and the substance. All of these dimensions are interrelated; they co-exist and are transformed together as a space: "The scale defines the size of the space, the metric defines the measurement of distances within the space, and the substance defines the non-spatial aspect of social objects" [author's translation] (Lévy, 1994: 69). 
The first aspect, namely the measurement of the space (or metric), concerns the dialectic relationship between the territory (or territories) and the network (or networks). It expresses the actors' mode of belonging through a connection with the borders of the territory or through connections between people (networks); these two modes for determining (and defining) what is inside the space and what is outside the space may coexist. This preferred mode of belonging to the space (territory and/or network of actors), as a dialectic relationship, is particularly important in the present case because the actors are continuously required to arbitrate between their position in a territory, within local or national organizations, and their desire to ensure the convergence of interests within a trans-border network or, at the very least, within an issue that goes beyond borders (globalization). The second aspect, that is the scale, defines the scope of the space. As Masson (2006: 139) explains, “Social relations are not only deployed 'in' space; the different economic and political processes that organize social relations and social life extend and stretch over different (and variable) expanses of space. The extent of such stretching is their scale." In our context, the scale of collective action represents its scope. In other words, it is the complex result of interactions within social movements and of interactions with the environment, including institutions. Here, an action that takes place locally can have a global scope, even if the target is the local government. The scales of action can depend directly upon the institutional organizations but, at other times, they are disconnected from them. The third aspect, which is the substance, refers to the content of the space (what occurs there). It involves the processes through which the actors arrive at common meanings, that is, common collective identities. Here again, these processes are riddled with conflicts, compromises and power struggles among the actors that must be taken into account. Under no circumstance is this context static; it is constantly being redefined and, for the analyst, it is a matter of identifying pivotal "moments" that highlight the processes through which actors derive meaning.

In the next two sections, we use this analytical framework to examine the transformations of the global space of protest in France, with emphasis on the changing place of the have-nots in this space. More specifically, we see how the emergence and development of this space was, firstly, the result of the convergence of actors around new contents of mobilization and new scales of actions. During a second period, the space was marked by a redefinition of its metric (belonging to a territory or network) and of its objectives. These transformations divided actors 
and limited concrete opportunities for convergence. The have-nots were thus pushed to the margins of the global space of protest.

\section{The Have-Nots at the Heart of Alter-globalization: A History of the Convergence of Fights}

If we follow the analysis conducted by Agrikoliansky (2005), who compiled the genealogy of the "alter-globalist" movement in France, social actors entered the global space of protest with the mobilizations against the debt of third-world countries in the late 1980s. This first and formative period explains the central role of international solidarity associations in creating a "global space of protest." During the 1990s, it was, rather, the rising movement of the unemployed, independent of union organizations, that played a central role in the development of alterglobalist struggles and that brought social issues back to the heart of protest actions.

Redefining social issues: renewed content in the global space of protest

As several analysts have underscored, the emergence of new protest organizations in the late 1980s and early 1990s was first observed in connection with the social issue (Sommier, 2008), and more specifically in the fight against unemployment. In fact, the first mobilizations of associations of the unemployed and the fights against unemployment appeared in the context of high unemployment rates (Demazière, 1997; Pendariès, 1995). The three main organizations eventually joined efforts with the CGT-chomeurs committee to represent the socially excluded. ${ }^{4}$ Each of these actors had ties with left and extreme-left political parties, and many of their early leaders were former unionists. While these actors did not attain great visibility on the French political scene in the early 1990s, from the end of the 1990s, the unemployed were, at least temporarily, a "unified" social force and of which other political actors considered. As a result, the demonstrations that took place in the winter of 1997 marked a defining moment in their history in that the four organizations promoted many of the same issues (reduction of working hours, emergency measures for all unemployed persons, guaranteed minimum income) and built some convergences among them. ${ }^{5}$ The emergence of this contestation in tension with union 
organizations also played a role in rebuilding the solidarity between workers and the unemployed. In addition to the right to work and the defense of work-as-we-know-it (a task traditionally carried out by the unions), organizations fighting against unemployment advocated the adoption of unconditional minimum income for all (workers and non-workers) (AC!, 19982002; Perrin, 2001: 79-80). This initial position was a major source of division between the organizations of the unemployed and the unions and the Parti communiste français (PCF French Communist Party), the latter two organizations having a relatively defensive position with respect to labor (CGT interview, 2001; PCF interview, 2001; Chemin and Fenoglio, 1996; Pierru, 2005: 178-179). In 2001, CGT and Force Ouvrière (FO - Workers' Force) supported unemployed organizations as did the Solidaires, Unitaires, Démocratiques unions (SUD Solidarity, Unity, Democracy) (SUD-PTT, 2001). AC! played a crucial role in the convergence process as well.

Also making an appearance in the fight against unemployment was the convergence of interests and identities of activists involved in sometimes-competing groups or, at least, in groups with very different positions on the French political scene. Certain organizations of the unemployed (the AC! in particular), the SUD unions, the Ligue communiste révolutionnaire (LCR - Revolutionary Communist League) and the PCF established stronger connections. The convergence of these interests and identities, clearly marked by the national territory, quickly came to include transnational referents.

New scales: the struggle against globalization beyond national borders

Beginning in the mid-1990s, organizations of the unemployed as well as union organizations (old and new) included "the fight against liberal globalization" in their activist discourses and practices. This emerging rhetoric went hand in hand with the gradual expansion of struggles beyond national borders.

The major mobilizations of December 1995 constituted a turning point for the shift from national scale of protest to a more global one (Béroud and Mouriaux, 2001). For most of the actors concerned, it was not only the national State that should be blamed for the meager living conditions of French citizens; other supranational institutions (including the European Union) were also held responsible. Similarly, connections were established among the discourses of 
unemployed Europeans and European workers who found themselves in the same situation, though to a different degree. In the spring of 1997, a call went out for the organization of European marches against unemployment. Hundreds of activists crossed Europe, and the marches culminated in Amsterdam on June 14, 1997 with a demonstration of 50,000 people.

In addition to the convergence of the unemployed with their European counterparts (Germany, Italy, Spain, Ireland and Belgium in particular), a second form of convergence occurred in France between movements of the unemployed, movements of the homeless, and movements of undocumented persons. This convergence took place at a national level between AC!, Droit au logement (DAL - Right to Housing) and Droits devant! (DD! - Rights First!), and at a European level as well. Mouchard draws a parallel between the progressive Europeanization of have-not movements between 1996 and 1999 and the increasingly strong connections they established with other organizations involved in the fight against globalization. The 1998 mobilizations against the Multilateral Agreement on Investments was one occasion during which organizations and activists brought their struggles closer together (Mouchard, 2005). Later, the creation of ATTAC formalized these connections, turning the fight against globalization into a transnationalization lever for some of the have-not organizations. ATTAC'S first board of directors, presided by Bernard Cassen of Le Monde Diplomatique, included activists from havenot organizations: Christophe Aguitton for AC! and Jean-Claude Amara for DD! (Mouchard, 2005: 320).

It was with the creation of the No-Vox network in 2002 at the European Social Forum (ESF) in Florence, which became a global network during the World Social Forum (WSF) of Porto Alegre in 2003, that the scope of the have-not movements became global. In 2007, the network included 28 grassroots organizations in Europe, Latin America, Asia and Africa (NoVox Activity Report, 2007). No-Vox describes itself as a "network of grassroots social movements and organizations of 'deprived peoples' (from work, from housing, from legal residence, from earnings etc.)", 6 and includes AC!, the European marches, DAL and DD. In Europe, No-Vox has member groups in France, Portugal and Belgium. Its presence, though relatively marginal at the outset, was fortified with the European and World Social Forums. During the ESF of Athens in May 2006, the theme "Precariousness, Poverty, Exclusion: The Transversality of Fights" was organized for the first time, providing added visibility to the havenots. At the ESF of Malmö in 2008, two of the themes directly involved issues related to poverty 
and exclusion: "Building labour strategies for decent work and dignity for all - against precarity and exploitation" and "Working for a Europe of inclusiveness and equality for refugees and migrants - fighting against all forms of racism and discrimination” (ESF, 2008).

Hence in the mid-1990s, the French global space of protest was no longer a space of protest for causes located outside of the national borders (in countries of the South); rather, it offered an opportunity to establish a direct connection between the problems experienced at the national level and global phenomena (the neo-liberal version of capitalism).

\section{A space marked by the division of work among activists}

In the early 2000 s, the French global space of protest was characterized by a division of tasks among the collective actors involved. On one side were the activists and organizations or networks involved in direct action in which the have-nots occupied a prominent place. On the other were the individuals (intellectuals), organizations such as ATTAC and networks that carried out the "intellectual work" and analyzed the fights (Mathieu, 2005: 153). This other groups plays like an avant-garde, providing meaning to the actions; a meaning that was adopted by an association such as $\mathrm{AC} !^{7}$ This division of tasks was not new, of course; it was the result of the history of the movement of the unemployed (Pierru, 2005). What is interesting to note, rather, is that it has endured so long in the fight against globalization.

As we have seen, the global space of protest in France was marked by the issue of unemployment. Extreme-left political parties showed a strong presence from the outset; emerging unions (and the SUD unions in particular) were heavily involved, and radical discourse and action were typical of the early days. In fact, the movement of the unemployed, and AC! in particular, was characterized by the use of direct repertory of actions encouraging illegal occupation, civil disobedience and the organization of actions that attracted media attention, in order to gain visibility in public opinion (Perrin, 2004). The movements of the unemployed systematized the practice of counter-summits in Europe, which became a central characteristic of the European movement against globalization (Balme and Chabanet, 2008: 133-136).

AC!, DAL and DD! also pioneered a new model of activism. They initiated struggles that extended beyond cleavages between organizations (union, associations) and between individual situations (the unemployed, people living in precarious situations, unions activists, the homeless). 
These organizations had flexible, non-hierarchical forms. They were also highly critical of European societies and of the centrality of work in particular. Lastly, they advocated the notion that it was time for "another kind of politics." According to Sommier (2008), the AC! collectives in France were the first on the alter-globalist scene to arrive at decisions by consensus (and not by vote), with emphasis on debate. Since then, the will to create horizontal relationships, to focus on direct participation in the decision-making process and to encourage debates within organizations and networks became the ideological foundations upon which the "alternative" practices of alter activists were built. At the same time as this activist creativity was taking place, ATTAC as a "popular education movement focused on action" helped to formalize these practices and instill them with global "meaning." Through its scientific council, which provided a seal of expertise to the various analyses, ATTAC provide a counter-discourse to the dominant discourse and spread the "good word" within the global space of protest. Several studies have shown the high percentage of post-graduate students among ATTAC members (Poliak, 2008: 82; Gobille and Uysal, 2005), granting this organization a special place within the space of protest.

Multi-positioned actors can be found at the heart of this convergence work. Of course, the media-friendly Christophe Aguiton, involved in AC!, SUD and ATTAC, comes to mind, but so do all of the others who encouraged the transition from the "practical" to the "intellectual" work of alter-globalization (Garcia, 2007: 136). Thus, during the Nice Summit of 2000, the Peoples' Summit in Quebec in the spring of 2001 and the Genoa Summit in July of the same year, the struggles of the have-nots and the fights denouncing liberal globalization appeared to be increasingly connected or, at the very least, complementary. The confrontational climate that prevailed during these summits between the demonstrators and law-enforcement officials also placed the have-nots at the heart of the fight, with the demonstrators' know-how of direct action and "high-risk" militancy ${ }^{8}$ securing a place for them at the front lines.

The launching of the first World Social Forum in Porto Alegre in 2001 was a turning point for the have-nots in the French global space of protest. Tensions among the actors, present throughout the timeframe we are considering, became a dissonance that prevented the deepening of convergences. The preferred modes of belonging to the space were at the heart of the dissonance. 


\section{The Have-Nots at the Margins of the French Global Space of Protest: Dynamics Limiting Convergence}

As discussed in the previous section, the French global space of protest was built around mobilizations of the unemployed and the mass mobilizations of 1995. Beginning with the first World Social Forum in 2001, the most deprived individuals of French society were no longer at the heart of the space. This "decentering" process became a real issue for actors at the center; ATTAC, the Centre d'études et d'initiatives de solidarité internationale (CEDETIM - Center for International Solidarity Studies and Initiatives), SUD solidaire, the PCF, and the LCR being forced to ask themselves how to turn alter-globalization into a movement that was closer to workers or to the working class and less dominantly composed of "middle and homogenous class". 9 Data gathered during the ESF of Paris/St-Denis (Agrikoliansky and Sommier, 2005) also demonstrate that it was not simply a matter of perception. Alter-globalization in France enjoyed a great deal of support from the educated middle class. The have-nots themselves voiced their opposition to this exclusion of the excluded (Giraud et al., 2005: 192) and fought to a greater extent within the global space of protest to secure a place, or at least a presence, for themselves. Thus, the creation of the No-Vox network can be analyzed as the expression of the transnationalization of solidarities of have-nots and therefore as the history of the convergence of fights among have-not movements of this world (Mésini, 2009). It can also be interpreted as the expression of a necessity for have-nots, and especially for the French activists who founded the network, to ensure a medium that would allow for a presence in a space that was increasingly difficult to access at the national level. It was not without reason that No-Vox described itself at the outset as the voice of the have-nots at social forums. ${ }^{10}$

There are obviously several reasons for this shift of the have-nots away from the center of the global space of protest. Some might argue that it is based on a change in the dominant forms of collective action in the space, with the counter-summits gradually being crowded out by less conflicting and more heteroclite social forums (Agrikoliansky et al. 2007). It can also be argued that the transformation from anti-globalization to alter-globalization was accompanied by a 
change at the level of the dominant discourse (extending beyond the stage of opposition and entering into proposals as well as at the level of practices considered legitimate (with direct action and civil disobedience gradually losing ground after 2001) (Fillieule and Della Porta, 2006: 17-40). During this same period, events taking place on the margins of the forums and summits experienced a rise in popularity, supported by the most radical fringe elements of alterglobalization. Consider, for example, the creation of the intergalactic village at the countersummit in Évian in 2003 (Fillieule et al., 2004). Another example includes the direct actions organized by the have-nots during the World Social Forums (the occupation of a building in downtown Porto Alegre during the 2003 WSF constituting the birth of the global network NoVox). A third example is the creation of alternative spaces during the 2004 ESF in London. ${ }^{11}$ This transformation of alter-globalization undoubtedly played a role in pushing the have-nots to the periphery of the movement, insofar as the players with more resources (unions, organizations such as ATTAC) attempted to distance themselves from the more radical have-nots tactics and to create legitimacy with the wider public less inclined to accept "activist overflow." But there is more.

The structuring of the dynamics among the actors in the French global space of protest also appears to be a key factor in understanding the transformation. Two dimensions illustrate this proposition. Firstly, one of the pivotal organizations of the movement, ATTAC, underwent major transformations during this latter period thereby unraveling the prevailing situation and shifting the equilibrium point of the global space of protest. Secondly, the place and role of the extremeleft political parties changed as well, reinforcing the gradual marginalization of the have-nots who tended to avoid close connections with partisan organizations.

\section{Change of metric: a global space of protest reverting to territoriality}

ATTAC was built around "global claims centered exclusively on globalization" [author's translation] (Ancelovici, 2004: 54), including the implementation of the Tobin tax on international movements of capital, the reform of tax havens and the creation of the International Criminal Court (Wintrebert, 2007: 9-11). The showcasing of global issues resulted in considerable efforts on the part of ATTAC to build support networks throughout the world. Gradually, “ATTAC's protests came to focus on more traditional and national themes, such as 
the defense of the public service" [author's translation] (Ancelovici, 2004: 54). ATTAC-France's return to the national territory and the defense of the French model led to divisions within the organization, that is between those who supported the association because of its initial global claims (activists as well as certain local ATTAC organizations) and those who no longer saw a distinction between ATTAC and the classic French left organizations traditionally fighting for the defense of the state and its intervention. This transformation also had repercussions within the global space of protest, gradually pitting anti-liberals (for whom ATTAC had become the standard-bearer) against others, accused of being "social liberals" that is, open to the redefinition of the left outside of the State tradition (Ancelovici, 2004: 58). In addition to this first stream of cleavage, debates within ATTAC began to crystallize in 2002 between those who favored the creation of a relay in the partisan field (in order to ultimately take power) and those who wished to stay away from "politics" and focus their energy on the creation of counter-powers (CRISP, 2007: 29-39). This issue naturally impacted on all of the movements concerned with the issue of globalization; it has been a central element of the debates that have shaped social forums all over the world. However, even if ATTAC did not have a monopoly of this division, ATTAC took on a specific aspect within the organization, also shedding light on the existing connections among partisan organizations (or their current and former activists) and other actors in the global space of protest. Thus, after internal battles and in light of the virulent reactions of other European ATTAC organizations, ATTAC-France came out against the filing of a 100\% alter-globalist slate in the European elections of June 2004 (Poliak, 2008). In addition, the attempt at presenting a single candidate in the 2007 presidential election following the victory of the "No" side in the referendum on the Treaty establishing a Constitution for Europe and surrounding the emblematic alter-globalist figure of José Bové not only divided the movement, but ended in an abject failure (Mathieu, 2008).

These events revealed one of the fracture lines that existed between the various global spaces of protest, one that is very prominent in the case of France. With the exception of certain Trotskyists, most activists agree that the French "progressive forces" must operate in an era in which revolution is a thing of the past. However, not everyone is on the same page as to the most effective means for expressing resistance. Should diverse and varied counter-powers be created, uniting forces behind an anti-liberal avant-garde that is wary of involvement in partisan politics? Should a partisan relay for social struggles be created or, in contrast, should "alternative" modes 
of action be considered here and now? Within ATTAC, the dominant position-albeit one constantly challenged - has been to build the social movement capable of blocking the system (opposition against the Multilateral Agreement on Investment and the Treaty establishing a Constitution for Europe) outside of the partisan arena. From this perspective, the aim of collective action against globalization is not the transnationalization of solidarities, nor is it the WSF processes as a different way of doing politics. The building of solidarities beyond national borders and the involvement within social forums are, rather, a means for fighting against economic liberalism and not an end in and of themselves. In the early days of the building of the global space of protest, these distinct notions of resistance were able to coexist, with each collective actor having a place within the space. Since 2001-2002, however, coexistence has become more difficult.

The repositioning of ATTAC within the framework of the national territory (and not within the global resistance network) and its partiality toward a fight "to come" (as opposed to an alternative involvement here and now) were accompanied by a distancing of the have-not movements. The have-nots did not defend the French public service model and the objectives of the fight against liberal globalization they put forth, as well as the action strategies they preferred, placed them in conflictual situations with the other actors and with ATTAC in particular.

It is important to recall that the first mobilizations of the unemployed took place in a context where the plural left was in power (1997) and where the initial discourse involved proposing other perspectives than those defended by the French public-service model. For instance, the 1997 call of the "Nous sommes la gauche" (We Are the Left) network, signed by several have-not representatives, proposed radical political solutions to the various facets of the issue of social exclusion (guaranteed income, free movement of persons including undocumented immigrants) (Mouchard, 2002: 3). In other words, at the end of the 1990s, the claims of the burgeoning have-not movements were in need of a change in the methods for redistributing wealth and not the simple preservation of acquired rights. In addition, the have-nots developed an ambiguous relationship with the State which Mouchard describes as "self-limited radicalism" [author's translation] (Mouchard, 2002). The have-not mobilizations looked beyond the direct assumption of power to issues hinging on political and social recognition, allowing for the existence of subjects that were "independent" of the State and of the other actors involved in the field of social solidarity. As stated by a network of signatories of the No-Vox network, "In our 
opinion, the possibility or impossibility of a change in hegemony is not our problem. (...) The only thing we can do is to develop and cultivate practices of change" [author's translation] (2006). In other words, by adopting repertories of action bordering on civil disobedience, the have-nots attempted to disclose and denounce the social practices that were at the very root of the inequalities, without calling into question the institutional framework supporting these practices. From this perspective, the State is neither the main problem, nor is it the "natural" solution to the difficulties experienced by the socially excluded.

The points of convergence between the have-nots and an organization such as ATTAC when the global space of protest was first created were linked to the shared desire to build an extensive network of alliances around the world. The preferred modes of belonging to the space involved networks of actors more than they did the defense of a territory. In addition, the scales of collective action were expanding and each actor was able to benefit from the multiplication of networks of other actors beyond borders. In the second phase, the national territory once again became a central point of reference for many actors, including ATTAC, though multiple scales of action remained. The distance between the have-nots and ATTAC was widening. Increasingly, the participation of the have-nots in the various social forums was carefully evaluated and the decision of whether or not to take part depended as much, if not more so, on the desire to be present as on that to be included in the alter-globalist movement (No-Vox, 2006). ${ }^{12}$

In a somewhat mechanical fashion, the consolidation of ATTAC's place within the French global space of protest shifted the point of equilibrium that existed at the beginning of the period and that had allowed a division of tasks between the have-nots and the other actors. More and more, the have-not organizations found themselves outside the space, choosing whether or not to be included in it. Sometimes they were invited to take part and not on other occasions. The increasing role of extreme-left political parties in the global space of protest amplified this change, with the have-nots wishing to preserve their autonomy of action vis-à-vis the allied organizations.

\section{Widening disparities in the contents of the mobilizations}

The relationship between political parties and the global space of protest is an extremely complex one. On one hand, there is a very strong desire for autonomy from partisan organizations. For 
instance, ATTAC prohibits its members from using their affiliation with the association to promote their bid for election and the Charter of the first WSF was clear about the non-partisan nature of these forums (Mathieu, 2005: 155). At the same time, from a comparative perspective, the presence of extreme-left political parties within the French global space of protest was significant. In terms of material resources, the PCF was behind many initiatives, as a patron or facilitator (similar to the role of communist mayoralties in the organization of the ESF of Paris/St-Denis in 2003). The LCR was ever-present, through its publication Rouge, as well as with many activists involved in the party and in other networks of associations. The Greens were also active during social forums through their youth committees and participated in the organization of certain summits. For the other European social actors, this French characteristic is the source of many conflicts and limitations as regards the deployment potential of alterglobalization in France. At the same time, France was probably one of the places in Europe where the distrust of partisan organizations was strongest. Thus, all of the actors we interviewed talked about their fear of political hijacking.

Throughout the entire period, the extreme left was heavily divided as to the meaning and legitimacy to be afforded to the emergence of these new actors (the have-nots and their allies). Between 1995 and 1998, the PCF attempted to monopolize the representation of the excluded in the electoral arena and, as such, was required to serve as a preferred mediation tool for associations fighting against exclusion (Dufour, 2000). At the same time, the PCF was reticent of the movements of the unemployed because they continued to view them as workers without jobs and, as such, their representation by workers' parties or traditional unions was considered sufficient. ${ }^{13}$ In power with the plural left from 1997 to 2002, the PCF found itself in a delicate position with respect to the have-not mobilizations. Following the electoral defeat of 2002, the PCF gradually became closer to non-partisan organizations involved in the globalization issue. The setbacks since experienced on the electoral scene also pushed the PCF to this new space in an attempt to rebuild alliances. However, these alliances, or forms of cooperation, were created primarily with central actors (such as ATTAC) and not with the have-not organizations, which had too little structure and an unsteady political support.

The evolution of the LCR was opposite to that experienced by the PCF and, of course, in tension with it. The LCR had always been extremely dynamic on the political and social action fields and continued to establish connections with the various activist networks, to provide them 
with material support and to benefit from the multiple activisms of its members so as to heighten its presence in the space. Until December 2008, ${ }^{14}$ the LCR can be considered the main actor of "the left of the left" and a pivotal force in the global space of protest. It has also recently gained ground on the electoral field, with its new leader, Olivier Besancenot, having the support of a many young alter activists. However, while the LCR had a number of connections with the havenots and especially with mobilizations of undocumented persons, these relationships were not established on an equal footing among all of the actors. Concerned with preserving their autonomy from more powerful actors, the have-not organizations, which are dependent upon these actors for the purposes of their mobilizations and their participation in various events such as social forums, have been in the same time extremely critical of the extreme-left parties, including the LCR, and their objectives pursued on the electoral scene. For many activists, it is difficult to conceive that a political party could have objectives outside of itself and its electoral success, even if this party otherwise shows a great deal of solidarity regarding its action. It is important to recall that the have-nots' defiance toward political parties has become their trademark, and several analyses have demonstrated how this dimension is, in fact, one of main reasons for their longevity (Péchu, 2001: 98). As soon as political parties have assumed a greater role at the forefront of the global space of protest, the have-not organizations have kept "one foot in and one foot out" $" 15$ in order to avoid being hijacked by the parties and to prefer alliances with alternative movements outside of France (No-Vox statement, ESF, London, 15-17 October 2004). This mistrust of the other alter-globalization actors may appear surprising given that the have-not leaders have a past as LCR activists and are well-versed in the practices of extreme-left political parties (Mouchard, 2005: 326). It nonetheless remains one of the reasons underlying the construction/deconstruction of the French global space of protest.

According to Giraud et al.(2005), during the ESF of Paris/St-Denis in 2003, the have-nots (through the intermediary of the No-Vox network in particular) experienced a "paradoxal marginalization". Given the claims and social issues they raised (poverty, exclusion, precariousness), they should have been at the heart of the fight against neo-liberal globalization but due to the fragility of their mobilizations, their participation was not automatic and had to be planned (especially the funding of travel). However, this "paradoxal marginalization" was not simply structural in nature-it was also connected to the concomitant transformations of the location of the other collective actors involved in the building of the space. 


\section{Conclusion: Tensions Giving Rise to Limitations}

The transformations of the global space of protest described above indicate that during the first phase, from the mid- nineties to the turn of the century, the have-nots played a central role by anchoring early anti-globalist demonstrations and were at odds with the traditional organizations of representation (see Péchu 1996: 118 regarding DAL). They have actively participated in turning the fight against liberal globalization into an alternative to a political activism with no future, and favoring pragmatic solutions and a repertory of action with emphasis on direct action. However, in the second phase, from 2001 to 2008, it was the extreme-left partisan organizations and ATTAC that played a dominant role, returning the space of protest to a much more "classic" form in the French political landscape.

More specifically, an analysis of the metrics of this space reveals a significant division, especially during the second phase, between the actors who identified primarily with the national territory and the actors who were focusing on the creation of transborder networks. As we have seen, ATTAC emphasized the defense of the national territory and the French state model. Furthermore, it is symptomatic of this division that ATTAC-France links with the other national ATTAC organizations were built on a country-by-country basis: there is an international ATTAC, but no transnational ATTAC network. The PCF, despite major internal conflicts, shares ATTAC's view of the primary definition of belonging. In a rather different manner, the have-not organizations became involved in the global space of protest by building transnational networks, first on the European scale, then beyond. The have-not mobilizations do not favor the preservation of the French model - they are excluded from it. Instead, they forge common identities around the recognition of similar situations elsewhere and around the denunciation of (economic, racist and sexist) systems of domination that deprive them of their rights. The defense of "the right to have rights" is not connected to a territory, but rather to the recognition of a common human condition.

In terms of the scale of protest (its scope), we observe multi-scale activist practices in the majority of cases that are articulated with increasing aptitude by collective actors. In France, 
these multi-scale practices involved most of the social actors that were also involved in the European networks. However, according to the actors, significant differences appear in the definition of these scales of action. For the have-not organizations, the creation of the NoVox network was to allow for the presence of deprived people in the World Social Forums, ensuring that their voices would be heard. From this perspective, the strategy for expanding the scope of the movement aimed to exercise influence and create alternative spaces in which the claims of the have-nots would be discussed, debated and heard by other social actors. The building of solidarities beyond the territory of France was more of a response to the desire to experiment, here and now, with other types of social relationships. In the case of extreme-left political parties, ATTAC and the SUD unions, the building of a global scale of action was mainly a response to the globalization of economic liberalism and more representative of an "isomorphic" strategy of international institutions and multinational corporations than a quest for an independent scale of action (even if the social forums were created outside of international institutions and less in relation to them, they are self-proclaimed spaces and are independent of the agendas of international institutions). We are not suggesting that the phenomenon of social forums was simply a mechanical response to a globalized capitalism; social forums are much more than that. However, in the case of ATTAC-France, the source of the mobilization was based less on the creation of an "alternative global space" than on the desire to fight against economic liberalism. Thus, the social forums, networks of actors and the building of transnational solidarities were primarily vehicles to be used in the fight which is defined outside of these places.

In terms of content, the issue of globalization has been gradually transformed into a cleavage pitting the old left against the new left. It is not so much an anti/alter-globalist debate, opposing anti-capitalists against anti-liberals, than it is an issue of which political strategies to emphasize and the meaning behind the fight. Within ATTAC itself, considered by some to be a "new" organization, tensions exist between former communist and/or union activists for whom social transformation cannot occur outside of partisan political action and the unification of all anti-liberal forces, and others for whom the preferred pathway is collective action outside of the partisan field and the possibility of leaving open the space of protest. In the case of the old Left, the objective of the mobilization is the failure and retreat of economic liberalism, while in the case of the new Left, the process of the fight itself is preferred as a means for converging similar 
individual experiences concerning the denial of rights and status (Beauzamy, 2003: 4). For the have-nots, it is a matter of "not allowing the people that are most affected by neo-liberal globalization to become excluded from the field of political, social and cultural expression represented by the social forums" [author's translation] (No-Vox statement, May 2006). In this cleavage, expressed with much less zeal between the mid-nineties till 2001, LCR, PCF, ATTAC, and CEDETIM are opposed to other actors in the field, including the have-nots.

Our consideration of the have-nots in the global space of protest leads us to question, in a different manner, the political convergence work required for the survival of the have-nots as a movement. Several authors have shown how the main have-not organizations (AC!, DAL, DD!) gradually succeeded in getting the have-nots exist as a group (Sommier, 2001: 84-104), emphasizing the interdependence of social ills and their cumulative nature. Mouchard (2005) demonstrated how the protests progressively became Europeanized and internationalized. However, taken in a larger environment, as in the social forum spaces, it is no longer a question of simply accounting for the building of the movement itself, but also of identifying its existence with respect to the others. In this sense, the progressive marginalization of the have-nots in the French global space of protest is revealing of the contradictions that exist. While their fights and discourses are perfectly congruent with the contentions of the French alter-globalists, their place within the movement is neither guaranteed nor is it central. 
| ${ }^{1}$ The terms "alter-globalization" comes from the French "altermondialiste". It refers to anti-capitalist social movements fighting against the international integration of globalization. In its more generally accepted version, democracy, economic justice, and/or human rights are putting ahead of purely economic values. In the literature, some authors also refer to these movements as Global Social Justice Movements. From the late nineties to the beginning of $21^{\text {st }}$ century, they were called anti-globalization movements. But they add to their struggles, the will to propose alternatives and thus the name changed. 2 Our analysis is based on the following: secondary literature addressing alter-globalization in France; data collected during comparative research conducted in 2005 on "Collective Action and Globalization in Canada and in France" (research project - regular grant of the Social Sciences and Humanities Research Council of Canada (SSHRC) and the Fonds québécois de la recherche sur la société et la culture (Quebec Research Fund for Society and Culture) grant for young researchers, 2003-2006), including approximately 30 semi-directed interviews of the main French unions, leaders of the international sections of political parties, leaders of major associations and charitable organizations); interviews conducted in 2001 with the Paris and Lyon sections of the three organizations for the unemployed and with the leader of the national committee CGT-chomeurs (SSHRC post-doctoral research grant, 2000-2002). The three main organizations are: the Mouvement national des chômeurs et des précaires (MNCP- national movement for unemployed and precarious workers), the Association pour l'emploi, l'information et la solidarité (APEIS - Association for Employment, Information and Solidarity) and Action contre le chômage (AC!- Action against unemployment). The Confédération générale du travail (CGT - General Confederation of Labor) is the only union to have a specific committee, the CGT-chomeurs committee. Refer to the list of interviews provided in the bibliography.

${ }^{3}$ AC! interview, 2001 Mouvement national des chômeurs et précaires (MNCP - National Movement of the Unemployed and of People Living in Precarious Situations, interview, 2001. 4 See Clot and Pendariès (1997) for a complete presentation of these organizations and an interpretation of their success in the mid-1990s.

${ }^{5}$ AC! interview, 2001, MNCP interview, 2001; APEIS interview, 2001; CGT-chômeurs interview, 2001.

${ }^{6}$ See http://www.novox.ras.eu.org/site/?lang=en, consulted February 2009.

7 "From Porto Alegre to Davos, from job insecurity to employment of undocumented persons, we will all work together. The project is global, and our fights must be global. And, faced with the repression of our movement, we must maintain solidarity by increasing resistance." [author's translation] ( $A C$ ! Rhône Info, no.8, February 2001).

8 To adopt the expression of Fillieule et al. (2004: 48).

${ }^{9}$ Interviews, 2005.

${ }^{10}$ See No-Vox website, http://www.hns-info.net/article.php3?id article=4731, consulted February 2009.

${ }^{11}$ Breve, No-Vox. See, http://www.passerellesud.org/spip.php?article196, consulted February 2009.

${ }^{12}$ Pourre interview, 2006.

${ }^{13}$ PCF interview, 2001.

${ }^{14}$ In February 2009, the LCR was dissolved and replaced by a new anti-capitalist party (NPA).

15 To use the expression of the No-Vox network, http://www.hns-info.net/article.php3?id_article=4731

\section{References}

Ancelovici, Marcos. 2002. "Organizing against Globalisation: The Case of ATTAC in France", Politics and Society 30, 3, September: 427-464.

Ancelovici, Marcos. 2004. "Attac et le renouveau de l'antilibéralisme", Raisons politiques, 16, november $2004: 45-59$.
Frederic. Royall y-2-7 16:52

Mis en forme: Police :11 pt, Anglais (G.B.)

Frederic. Royall y-2-7 16:52

Mis en forme: Police :11 pt, Anglais (G.B.)

\begin{tabular}{|c|}
\hline Frederic.Royall y-2-7 16:52 \\
\hline Mis en forme: Police :11 pt, Anglais \\
\hline Frederic.Royall y-2-7 16:52 \\
\hline Mis en forme: Police :11 pt, Anglais \\
\hline Frederic.Royall y-2-7 16:52 \\
\hline Mis en forme: Police :11 pt, Anglais \\
\hline Frederic.Royall y-2-7 16:52 \\
\hline Mis en forme: Police :11 pt, Anglais \\
\hline Frederic.Royall y-2-7 16:52 \\
\hline Mis en forme: Police :11 pt, Anglais \\
\hline Fredèric.Royall y-2-7 16:52 \\
\hline Mis en forme: Police :11 pt, Anglais \\
\hline Frederic.Royall y-2-7 16:52 \\
\hline Mis en forme: Police :11 pt, Anglais \\
\hline Frederic.Royall y-2-7 16:52 \\
\hline Mis en forme: Police :11 pt, Anglais \\
\hline Frederic.Royall y-2-7 16:52 \\
\hline Mis en forme: Police :11 pt, Anglais \\
\hline Frederic.Royall y-2-7 16:52 \\
\hline Mis en forme: Police :11 pt, Anglais \\
\hline Frederic.Royall y-2-7 16:52 \\
\hline Mis en forme: Police :11 pt, Anglais \\
\hline Unknown \\
\hline Code de champ modifié \\
\hline Frederic.Royall y-2-7 16:52 \\
\hline Mis en forme: Police :11 pt, Anglais \\
\hline Frederic.Royall y-2-7 16:52 \\
\hline Mis en forme: Police :11 pt, Anglais \\
\hline Frederic.Royall y-2-7 16:52 \\
\hline Mis en forme: Police :11 pt, Anglais \\
\hline Frederic.Royall y-2-7 16:52 \\
\hline Mis en forme: Police :11 pt, Anglais \\
\hline Frederic.Royall y-2-7 16:52 \\
\hline Mis en forme: Police :11 pt, Anglais \\
\hline Frederic.Royall y-2-7 16:52 \\
\hline $\begin{array}{l}\text { Mis en forme: Police : } 11 \mathrm{pt} \text {, Anglais } \\
\text { (G.B.) }\end{array}$ \\
\hline
\end{tabular}


Agrikoliansky, Éric, Boris Gobille and Ilhame Hajji. 2007. "Que savons nous des militants altermondialistes ? Remarques sur la transnationalisation du militantisme à partir de deux enquêtes sociographiques", Communication, $2^{\text {nd }}$ Congrès des associations francophones de science politique, Laval University, Quebec, May 2007, 30p.

Agrikoliansky, Éric and Isabelle Sommier, dir. 2005. Radiographie du mouvement altermondialiste. Paris : La Dispute.

Agrikoliansky, Eric. 2005. "De l'anticolonialisme à l'altermondialisme: généalogie(s) d'un nouveau cadre d'action collective". In, Agrikoliansky, Éric, Olivier Fillieule and Nonna Mayer. L'altermondialisme en France. La longue histoire d'une nouvelle cause. Paris: Flammarion: pp.4- 36.

Agrikoliansky. Éric, Olivier Fillieule and Nonna Mayer. 2005. L'altermondialisme en France. La longue histoire d'une nouvelle cause. Paris : Flammarion.

Aguiton, Christophe. 2002. O mundo nos pertenece. Sao Paulo: Viramundo.

Balme, Richard and Didier Chabanet. 2008. European Governance and Democracy: Power and Protest in the EU. Lanham, Md.: Rowman and Littlefield.

Beauzamy, Brigitte. 2003. "Danger : Work. Representation and mobilization of the unemployed in radical anti-globalization movements", European Consortium for Political Research, $2^{\text {nd }}$ General Conference, Marburg, Germany, September 18-21.

Sophie Béroud and René Mouriaux. 2001. Le Souffle de l'hiver 1995. Paris : Éditions Syllepse.

Belorgey, Jean-Michel. 2000. Minima sociaux, revenus d'activité, précarité. Rapport du Commissariat Général du Plan. Paris : La Documentation française.

Chabanet, Didier. 2002. "Les marches européennes contre le chômage, la précarité et les exclusions ». In Balme Richard, Didier Chabanet et Vincent Wright, dir., L'action collective en Europe. Paris : Presses de sciences po, pp. 461-493.

Chabanet, Didier and Jean Faniel. 2009. Mobilisations de chômeurs : problématiques d'alliances ou alliances problématiques. Paris : L'Harmattan (Forthcoming).

Chemin, Ariane and Jérôme Fenoglio. 1996. "Les syndicats et les partis restent éloignés des chômeurs". Le Monde (Paris), 13 November 1996 : 9.

Clot, Yves and Jean-René Penderiès. 1997. « Les chômeurs en mouvement » (Convention de recherche n.16/95). Paris: MIRE.

Crettiez, Xavier and Isabelle Sommier. 2006. La France rebelle. Tous les mouvements et acteurs de la contestation. Paris : Michalon.

della Porta, Donatella. 2005. "Protest on Unemployment : Forms and Opportunities". In Marco Giugni, dir., The contentious politics of unemployment in Europe: Political Claims-making, Policy Deliberation and Exclusion from the Labour Market, Rapport final, Projet Unempol, Commission Européenne. Available On Line: http://ics.leeds.ac.uk/eurpolcom/unempol/reports.cfm

della Porta, Donatella et al. 2006. Globalization from Below : Transnational Activists and Protest Networks. Minneapolis: University of Minnesota Press.

Demazière, Didier. 1997. "Des chômeurs sans représentation collective: une fatalité?». Problèmes économiques 2, 509 (February) : 20-25.

Demazière, Didier and Maria-Teresa Pignoni. 1998. Chômeurs : du silence à la révolte, Paris : Hachette.

Dufour, Pascale. 2000. Citoyenneté et hors-travail: la construction politique d'un nouvel espace social. Une perspective comparée. Ph.D thesis, Political science, University of Montreal. 
Dufour, Pascale. 2006. "Projet national et espace de protestation mondiale : des articulations distinctes au Québec et au Canada", Revue canadienne de science politique, 39 : 315-342.

European Social Forum. 2008. On Line, consulted, September, 112008 http://www.esf2008.prg/program/themes-for-esf2008-10-14

Fillieule, Olivier and Donatella Della Porta. 2006. Police et manifestants. Maintien de l'ordre et gestion des conflits. Paris : Presses de Sciences Po.

Fillieule, Olivier. 1993. "Conscience politique, persuasion et mobilisation des engagements. L'exemple du syndicat des chômeurs, 1983-1989”. In Olivier Fillieule, ed. Sociologie de la protestation. Les formes de l'action collective dans la France contemporaine. Paris : L'Harmattan, pp. 123-155.

Fillieule, Olivier, Philippe Blanchard, Éric Agrikoliansky, Marko Bandler, Florence Passy and Isabelle Sommier. 2004. "L'altermondialisme en réseaux. Trajectoires militantes, multipositionnalité et formes de l'engagement: les participants du contre-sommet du G8 d'Evian", Politix, 17 (68) : 13-48.

Garcia, Guillaume. 2007. "Le mouvement de 'sans': investir l'espace public comme une ressource compensatoires". In Boumaza, Magali and Philippe Hamman, ed. Sociologie des mouvements de précaires. Espaces mobilisés et répertoires d'action. Paris : L'Harmattan, pp.131-154.

Giraud, Baptiste, Guillaume Garcia, Daniel Mouchard and Karen Yon. 2005. "La question sociale au Forum social”. In Éric Agrikoliansky and Isabelle Sommier, Radiographie du mouvement altermondialiste. Le second Forum social européen. Paris : La dispute, pp.187212.

Gobille, Boris et Aysen Uysal. 2005. “Cosmopolites et enracinés”. In Éric Agrikoliansky and Isabelle Sommier, ed. Radiographie du mouvement altermondialiste. Paris : La Dispute, pp. $105-126$

Hmed, Choukri. 2007. "Aux marges de l'altermondialisme: la représentation des classes populaires issues de l'immigration au deuxième forum social européen". In Cadiou, Stéphane, Stéphanie Dechezelles and Antoine Roger, ed. Passer à l'action: les mobilisations émergentes. Paris. L'Harmattan, pp.249-269.

Imig, Doug and Sidney Tarrow. 2001. "Mapping the Europeanisation of Contention : Evidence from a Quantitative Data Analysis “. In Doug, Imig et Sidney Tarrow, ed. Contentious Europeans. Protest and Politics in an Emerging Polity. Lanham : Rowman \& Littlefield, pp. 27-53.

Lévy, Jacques. 1994. L'espace légitime. Paris: Presses de la Fondation Nationale des Sciences Politiques.

Masson, Dominique. 2006. "Constructing Scale / Contesting Scale: Women's Movement and Rescaling Politics in Quebec “. Social Politics: International Studies in Gender, State and Society 13, 4 (winter): 462-486.

Maurer, Sophie and Emmanuel Pierru. 2001. "Le mouvement des chômeurs de l'hiver 19971998. Retour sur un 'miracle social'”. Revue française de science politique, 51, 3 (June) : 371 407.

Mathieu, Lilian. 2008. “Trouble dans le genre militant. L'échec de la candidature unitaire au regard des décalages entre champ politique et espace des mouvements sociaux ". In Geay Bertrand and Laurent Willemez, ed. Pour une gauche de la gauche. Paris: Éditions du croquant, pp. 93-112. 
Mathieu, Lilian. 2007. "Les mobilisations improbables: pour une approche contextuelle et compréhensive “. In Cadiou, Stéphane, Stéphanie Dechezelles and Antoine Roger, ed., Passer à l'action : les mobilisations émergentes. Paris : L'Harmattan, pp. 187-198.

Mathieu, Lilian. 2005. "La constitution du mouvement altermondialiste français", Critique internationale, 27 (April-June) : 147-161.

Mathieu, Lilian. 2004. Comment lutter? : Sociologie et mouvements sociaux. Paris : Textuel.

Mésini, Béatrice. 2009. "Les mouvements de Sans dans les Forums sociaux. Luttes aux confins et lignes de confront", Research Note, Politiques et Sociétés, Spring.

Mouchard, Daniel. 2007. "Sur la «nouveauté» des mobilisations. Quelle pertinence pour la problématique de l'émergence? “. In Cadiou, Stéphane, Stéphanie Dechezelles and Antoine Roger, ed., Passer à l'action : les mobilisations émergentes. Paris : 1'Harmattan, pp. 291-297.

Mouchard, Daniel. 2002. "Les mobilisations des «sans» dans la France contemporaine: l'émergence d'un " radicalisme autolimité »? ". Revue française de science politique, 4, 52 : 425-447.

Mouchard, Daniel. 2005. "Le creuset de la mobilisation anti-AMI de 1998". In Éric Agrikoliansky, Olivier Fillieule et Nonna Mayer, ed. L'Altermondialisme en France. La longue histoire d'une nouvelle cause. Paris : Flammarion, pp. 317-337.

No-Vox. 2006. "Qui sont-ils ceux pour qui nous voulons changer le monde?". On Line, consulted September, 15 2008. http://www.novox.ras.eu.org/site/spip.php?article70

No-Vox. 2007. Activity Report. Unpublished document.

No-Vox. 2004. Statement, European Social Forum, London, 15-17 October 2004. On Line, consulted September $\quad 15, \quad 2008$ : http://74.125.47.132/search?q=cache:Eli8iR6j5jAJ:clamartiens.free.fr/journal_ac/BAC2/Page $\% 25202 . p d f+N o-$

Vox,+ un + pied + dedans + un + pied + dehors + londres $\& h l=$ fr $\& \mathrm{ct}=\mathrm{clnk} \& \mathrm{~cd}=9 \& \mathrm{gl}=\mathrm{ca} \& \mathrm{client}=$ firefo $\mathrm{x}-\mathrm{a}$

Péchu, Cécile. 1996. “Quand les 'exclus' passent à l'action. La mobilisation des mal-logés “. Politix, 9, 34 : 114-133.

Péchu, Cécile. 2001. "Les générations militantes à Droit au Logement". Revue française de science politique, 51, 1-2:72-103.

Penderiès, Jean-René. 1995. "Les mouvements des chômeurs et des précaires : contradictions et enjeux “, $M 78: 3-10$.

Pierru, Emanuel. 2005. Guerre aux chômeurs ou guerre au chômage. Paris : Éditions du Croquant.

Polliak, Claude. 2008. "ATTAC. Aux frontières du champ politique “. In Bertrand Geay et Laurent Willemez, ed., Pour une gauche de gauche. Paris : Éditions du Croquant, pp. 75-90.

Perrin, Évelyne. 2004. Chômeurs et précaires au cœur de la question sociale. Paris: La Dispute.

Pourre, Annie. 2006. "No-Vox et les forums sociaux", Europe Solidaire Sans Frontières. On Line, consulted September, 20 2008. http://www.europe-solidaire.org/spip.php?article2114

Royall, Frédéric. 2009. "Regards croisés: La presse frontiste face aux mouvements des "sans" dans les années 1990", French Politics, Culture and Society 27, 1.

Royall, Frédéric. 2004. "Politics and unemployment in France". Modern and Contemporary France 12, $1: 49-62$.

Sikking, Kathryn. 2005. "Patterns of Dynamic Multilevel Governance and the Insider-Outsider Coalition". In Della Porta et Tarrow, dir. Transnational Protest and Global Activism. Lanham: Rowman and Littlefield, pp. 192-226. 
Sommier, Isabelle. 2001. Les nouveaux mouvements contestataires à l'heure de la mondialisation. Paris : Flammarion.

Sommier, Isabelle. 2008. "La gauche mouvementiste et l'aspiration à une politique autrement ". In Bertrand Geay and Laurent Willemez, ed. Pour une gauche de gauche. Paris : Éditions du Croquant, pp. 57-73.

Tarrow, Sidney. 2007. "Militantisme transnational et cosmopolite enraciné ", Lien social et politiques, 58, Fall.

Wintrebert, Raphaël. 2007. "ATTAC France et le mouvement altermondialiste", Courrier hebdomadaire, 1978-1979: 5-62.

Interviews:

1) A first set of interviews was conducted in April 2001 on the theme "Collective Action of the Excluded."

- Parti Communiste Français (PCF - French Communist Party), Isère Departmental Office, group interview, April 2001.

- Confédération générale des travailleurs (CGT - General Confederation of Workers), Isère Division, group interview, April 2001.

- CGT-chômeurs, National Office, spokesperson, April 2001.

- Mouvement national des chômeurs et des précaires (MNCP - National Movement of the Unemployed and of People Living in Precarious Situations), Paris Office, group interview, April 2001.

- Association Agir contre le chômage (AC! - Act against Unemployment), National and Regional Office (Rhone-Alps), group interview, April 2001.

- Association pour l'emploi et la solidarité des chômeurs et des précaires (APEIS Association for the Employment and Solidarity of the Unemployed and of People Living in Precarious Situations), National Office, group interview, April 2001.

- SUD-PTT unions, Toulouse Office, group interview, Juillet 2001

- Parti des Verts (Green Party), South-West Regional Office, spokesperson, July 2001.

2) A second set of interviews was conducted in May 2005, in Paris and Marseille, on the theme "Collective Action and Globalization." Insofar as possible, I met with the individuals in charge of the globalization issue. 
- Political parties: Parti Socialiste (PS - Socialist Party), Parti Communiste (PC Communist Party), Union pour la Majorité Présidentielle (UMP - Union for Presidential Majority), Parti des Verts (Green Party), Front national (National Front), Ligue Communiste Révolutionnaire (LCR - Revolutionary Communist League)

- Unions: Confédération française démocratique du travail (CFDT - French Democratic Confederation of Labor) / Confédération générale des travailleurs (CGT - General Confederation of Workers) / Union solidaire - Sud, Confédération Paysanne (Peasant Confederation)

- Organizations: Mouvement des enterprises de France (MEDEF - Employers' Organization of France)

- Groups and NGOs: Association pour la taxation des transactions pour l'aide aux citoyens (ATTAC - Association for the Taxation of Financial Transactions to Aid Citizens) (Paris and Marseille), Act-Up, Droit au logement (DAL - Right to Housing), Agir contre le chômage ! (AC! - Act against Unemployment), Centre d'études et d'initiatives de solidarité internationale (CEDETIM - Center for International Solidarity Studies and Initiatives), Secours Catholique (Catholic Rescue), World March of Women, Paris and Marseille 